\title{
QUARTERLY ANALYSIS: \\ The Progress of Monetary, Banking and Payment System \\ Quarter I - 2011
}

\author{
Author Team of Quarterly Report, Bank Indonesia
}

The Board of Governors Meeting (Rapat Dewan Gubernur/RDG) of Bank Indonesia on 12 April 2011 has decided to maintain the Bl rate by $6.75 \%$. This decision does not change the direction of Bank Indonesia's monetary policy which tends to be strict in an effort to control the inflationary pressures that are still high, amid the government efforts to reduce inflationary pressure from volatile foods group. The Board of Governors considered that the strengthening of the rupiah so far can reduce these inflationary pressures, particularly from the rising price of international commodities (imported inflation). In addition, to minimize the negative impact of short-term foreign capital flows on monetary stability and financial system, the Board of Governors also has decided to replace the one-month holding period on SBI to six-month holding period, which shall take effect on May 13, 2011. Looking ahead, Bank Indonesia assessed that the possibility of the $\mathrm{BI}$ rate level adjustment is still open to dampen the incoming inflationary pressures. Bank Indonesia believed that the implementation of monetary and macro-prudential policy mix, supported also by the strengthened coordination of government policy, will be able to maintain the macroeconomic stability and bring inflation to the target, which are $5 \% \pm 1 \%$ in 2011 and $4.5 \% \pm 1 \%$ in 2012 .

The Board of Governors considered that the global economic recovery in the future is better as seen from the upward adjustment of global economic growth projections by various international agencies. This improvement of global optimism will have an impact on world trade volume which has now also increased. This will have positive influence on the demand for export products to help encouraging domestic economic growth. However, the process of global economic recovery is still faced with the uncertainties related to the risk of debt crisis that hit several countries in Europe and the potential disruption of production after the earthquake in Japan. In addition, the rising prices of oil and global food commodity are predicted to continue which cause inflationary pressures in many developed countries and emerging economies, including Indonesia. 
On the domestic side, the Board of Governors observed that Indonesia's economic growth is forecasted to increase by 6.0 to $6.5 \%$ in 2011 and 6.1 to $6.6 \%$ in 2012 . This economic recovery is underpinned by a more balanced source of growth in line with the improving investment performance and the export performance that remains solid. In the second quarter of 2011, economic growth is forecasted to grow quite high at $6.4 \%$. The role of investment to increase the capacity of the economy, especially through FDI, is expected to rise in line with the demand that remains strong, both from domestic and external, and also with the improvement in sovereign credit rating. By sector, all sectors of the economy are predicted to grow high, with the highest growth in the sector of transport \& communication, trade, hotels \& restaurants, and construction.

The performance of Indonesia's balance of payments recorded a surplus which is estimated to be still high enough in 2011. This surplus is derived either from the current account or from the capital and financial transactions. Export is forecasted to grow quite high. Capital inflows, in the form of portfolio, are predicted to remain large, while the foreign direct investment (FDI) is expected to increase. With such development until the end of March 2011, foreign reserves stood at 105.7 billion U.S. dollars, equivalent to 6.3 months of imports and foreign debt payments.

The strengthening trend in rupiah continued in March 2011. In addition to being in line with the performance of BOP, which recorded a grand surplus and foreign investors' positive perception toward the strength of Indonesia's economic fundamentals, the strengthening of rupiah is also a part of Bank Indonesia's policy response to control inflationary pressures, particularly from the rising prices of international commodity (imported inflation). Until the end of March 2011 the rupiah was strengthened by 3.47\% (ptp) to Rp8.708 per U.S. dollar. This appreciation to Rupiah has not so far affected the competitiveness of Indonesia in terms of the exchange rate, among others, reflected in the performance of Indonesia's non-oil exports which continue to show a relatively high improvement.

In regard to price, although the inflation has shown a declining trend, the risk of future inflation pressures is expected to remain quite high. CPI inflation in March 2011 reached 6.65\% (yoy) or deflation of $0.32 \%(\mathrm{mtm})$ in line with inflation correction in alimentation products. Although it is still relatively high, the inflationary pressure from the volatile foods group showed a declining trend in line with the Government measures to strengthen the national food. Meanwhile the moderate inflation of administered prices is associated with the minimum price adjustment policies by the Government. However, the core inflation showed an increasing trend, which was recorded at $4.45 \%$ (yoy) or $0.25 \%$ (mtm) in March 2011, as the propagated impacts of the high prices of food and the rising inflation expectations. Looking ahead, the risk 
of inflationary pressures is expected to remain relatively high, influenced by the rising prices of international commodity, the high domestic demand, and the high inflation expectations. Bank Indonesia will continue to be alert to the risk of inflationary pressures and strengthen the mixture of monetary and macro-prudential policy to control the inflation targets.

The stability of financial system is maintained along with the continuing improvement of the intermediation function of banks and the banking liquidity which is in control. The banking industry is under a stable condition characterized by the sustained capital and liquidity as reflected in the high capital adequacy ratio (CAR) at the level of $18 \%$ and the ratio of nonperforming loans (NPL) which is maintained fewer than $5 \%$ gross. The banking intermediation is also getting better reflected in the rising credit growth, which in March 2011 reached $25.1 \%$ (yoy), supported by the growth in all types of loans including loans to Small Medium Enterprises (SMEs). 
This page is intentionally left blank 